\title{
Vitamin D receptor polymorphisms: are they really associated with type 1 diabetes?
}

\author{
M G Bianco, L Minicucci, M G Calevo ${ }^{1}$ and R Lorini \\ Department of Pediatrics, University of Genoa and ${ }^{1}$ Epidemiology and Biostatistics Service, Scientific Direction IRCCS, G. Gaslini Institute, 16147 Genoa, \\ Italy \\ (Correspondence should be addressed to L Minicucci; Email: lauraminicucci@ospedale-gaslini.ge.it)
}

In their interesting paper, Turpeinen et al. (1) studied the effects of polymorphisms of the vitamin D receptor (VDR) gene on the susceptibility to type 1 diabetes mellitus (T1DM) in a large case-control series from the Finnish population. Recent studies have clarified the molecular basis of the immunomodulatory activity of vitamin $\mathrm{D}$ which has been observed to inhibit T-cells and cytokine production (2). Moreover, vitamin D deficiency is considered to be associated with increased risk of T1DM (3). The biological effects of vitamin D, by interaction through VDRs and the association between allelic variants of the VDR gene and susceptibility to T1DM, have also been studied (4). To date, published results have been controversial. Studies carried out on European populations - using PCR and Apa I, Bsm I and Taq I restriction enzymes - showed a significantly higher incidence of the genotype AABBtt in type 1 diabetic patients than in normal subjects $(5,6)$. Turpeinem et al. (1) genotyped for VDRA (Apa I), VDRB (Bsm I) and VDRF (Fok I) single nucleotide polymorphisms using a mini-sequencing reaction. The authors concluded that the single nucleotide polymorphisms analysed are unlikely to be associated with T1DM in the Finnish population. Recently we compared polymorphisms of the VDR gene in a group of T1DM patients (group A) and in a group of normal subjects (group B). Group A consisted of 31 patients followed at our Genoa Centre (21 males, mean age 10 years, range $2-22.5$ years) and group B consisted of 36 blood donors (24 males, mean age 33 years, range 20-39.8 years). VDR genotyping was performed using PCR and Bsm I, Apa I and Taq I restriction enzymes, in order to identify alleles A, a, B, b, T and t. VDR gene polymorphisms were compared between patients and controls using the $\chi^{2}$ test and Fisher exact test (Table 1). Our data show that there is no relationship between the VDR gene and T1DM susceptibility, except for a significantly higher frequency of the genotype AaBbTt in controls compared with diabetic patients. Moreover, we observed that the frequency of the genotypes AaBbTT and AABbTt was higher in group A patients than in group $B$ subjects, but not significantly. To our knowledge, this is the first study on an Italian population and, even though the data are from a small series, our experience, in contrast to the Finnish study, does not confirm that polymorphism of the VDR gene has a role in the susceptibility to T1DM.

Table 1 Genotype frequencies, and $\chi^{2}$ and $P$ values for controls (36) and T1DM patients (31).

\begin{tabular}{|c|c|c|c|c|c|c|}
\hline Genotypes & Controls, $\boldsymbol{N}(\%)$ & T1DM patients, $\boldsymbol{N}(\%)$ & OR & $x^{2}$ & Cl $95 \%$ & $P$ \\
\hline aabbTT & 5 (13.9) & $2(6.5)$ & 0.43 & 0.97 & $(0.05-2.80)$ & 0.28 \\
\hline AabbTT & 4 (11.1) & $2(6.5)$ & 0.55 & 0.44 & $(0.06-3.92)$ & 0.41 \\
\hline AaBbTt & 15 (41.7) & 5 (16.1) & 0.27 & 5.11 & $(0.07-0.97)$ & 0.02 \\
\hline AaBbTT & 0 & $3(9.7)$ & 8.96 & 3.59 & $(0.44-180)^{\prime}$ & 0.09 \\
\hline AaBBTt & $1(2.8)$ & $1(3.2)$ & 1.17 & 0.01 & $(0.01-94)$ & 0.71 \\
\hline AAbbTT & 0 & $1(3.2)$ & 3.59 & 1.16 & $(0.14-91)$ & 0.46 \\
\hline AABbTt & $1(2.8)$ & $5(16.1)$ & 6.73 & 3.59 & $(0.69-161)$ & 0.07 \\
\hline AABbTT & $1(2.8)$ & $1(3.2)$ & 1.17 & 0.01 & $(0.01-94)$ & 0.71 \\
\hline AABBtt & 5 (13.9) & $6(19.4)$ & 1.49 & 0.36 & $(0.35-6.91)$ & 0.55 \\
\hline AABBTt & $4(11.1)$ & $4(12.9)$ & 1.19 & 0.05 & $(0.22-6.39)$ & 0.56 \\
\hline AABBTT & 0 & $1(3.2)$ & 3.59 & 1.16 & $(0.14-91)$ & 0.46 \\
\hline
\end{tabular}

OR, odds ratio; $\mathrm{Cl}$, confidence interval. 


\section{References}

1 Turpeinen H, Hermann R, Vaara S, Laine A, Simell O, Knip M, Veijola R \& Ilonen J. Vitamin D receptor polymorphisms: no association with type 1 diabetes in the Finnish population. European Journal of Endocrinology 2003149 591-596.

2 Penna G \& Adorini L. 1 $\alpha, 25$-Dihydroxyvitamin D3 inhibits differentiation, maturation, activation, and survival of dendritic cells leading to impared alloreactive $\mathrm{T}$ cell activation. Journal of Immunology $20001642405-2411$.

3 Hypponen E, Laara E, Reunanen A, Jarvelin MR \& Virtanen SM. Intake of vitamin D and risk of type 1 diabetes: a birth-cohort study. Lancet $20013 \mathbf{3 5 8} 1500-1503$.

4 McDermott MF, Ramachandran A, Ogunkolade BW, Aganna E, Curtis D, Boucher BJ, Snehalatha C \& Hitman GA. Allelic variation in the Vitamin D receptor influences susceptibility to IDDM in Indian Asians. Diabetologia 199740 971-975.

5 Pani MA, Knapp M, Donner H, Braun J, Baur M \& Usadel K. Vitamin D receptor allele combinations influence genetic susceptibility to type I diabetes in German. Diabetes 200049 504-507.

6 Skrabic V, Zemunik T, Situm M \& Terzic J. Vitamin D receptor polymorphism and susceptibility to type 1 diabetes in the Dalmatian population. Diabetes Research and Clinical Practice 2003 $5931-35$.

Received 27 July 2004

Accepted 28 July 2004 